DOI 10.22363/2618-897X-2019-16-4-608-621

Research Article

\title{
Reading War and Peace as a Translingual Novel
}

\author{
Julie Hansen \\ Uppsala University \\ 75236 Uppsala, Sweden
}

This article re-examines Lev Tolstoy's novel Voina i mir (War and Peace) in light of recent research in the field of translingual literary studies. This Russian novel contains numerous passages, phrases, and words in French. Tolstoy's extensive use of the French language in a Russian novel puzzled many of his contemporary critics; it has also tended to be less visible in translations into other languages. The article surveys previous research on the multilingual dimension of War and Peace by well-known scholars such as Viktor Vinogradov, Viktor Shklovsky, Boris Uspensky, R. F. Christian, and Gary Saul Morson. Among the explanations offered for the presence of French in the text are realism, characterization, and ostranenie (defamiliarization). Applying Formalist principles and Thomas O. Beebee's concept of transmesis, the current article suggests a translingual reading of this canonical novel. The analysis focuses on selected passages in which multiple languages are at play, showing how they draw the reader's attention to language as a medium through depictions of code-switching and multilingual situations; metalinguistic commentary; biscriptuality; and code-mixing on the level of the text.

Key words: Tolstoy, "War and Peace”, translingual, multilingual, bilingual, French, transmesis

\section{Introduction}

Lev Tolstoy's novel Voina i mir (War and Peace) occupies a central place in the world canon. Since it was first published serially in the journal Russkii vestnik (Russian Herald) in 1865, it has been translated numerous times into English and other languages. The most recent of nearly a dozen English translations are by Anthony Briggs (2005), Andrew Bromfield (2007, a translation of Tolstoy's first version), Richard Pevear and Larissa Volokhonsky (2007), and Amy Mandelker (2010, a revision of Aylmer and Louise Maude's translation from 1922-1923). Yet an intrinsic aspect of this novel has, until recently, been less visible in translation, namely its translingual fabric, in which French is intricately woven into the Russian, along with accents of other languages. French is used in the novel to convey both oral and written communication - in letters, salon conversations, intimate tête-à-têtes, and war councils. Many of the characters, as well as the omniscient thirdperson narrator, code-switch, sometimes mid-sentence, and mix languages in a variety

(C) Julie Hansen, 2019

This work is licensed under a Creative Commons Attribution 4.0 International License 
of ways. The reader of the novel is confronted with its translingualism from the very start, as it opens with the French words of Anna Pavlovna Scherer greeting the first guest to arrive at her soirée. The reader is vicariously welcomed into the multlingual world of the salon, where the conversation, as Gary Saul Morson observes, "incorporates French, Russian, German, Italian, and English, and complex hodgepodges of these languages as characters jump from one to another" [1. P. 47].

Many of Tolstoy's contemporary Russian critics viewed the entire novel as a hodgepodge, as expressed in comments such as the following: "because of some inexplicable caprice, half of his [Tolstoy's] characters speak in French, and their entire correspondence is conducted in that language [...] To read a book that presents some sort of medley of 'French and Great Russian' without any need for it is truly inconvenient and unpleasant" " [3. P. 46]. Another critic faulted Tolstoy not for the French phrases per se, but for the extent of them:

Заметим автору, что в книге его странным кажется не это употребление французских фраз вместе с русскими, а чрезмерное, сплошное наполнение французской речью целых десятков страниц сряду. Для того, чтобы показать, что Наполеон или другое какое-либо лицо говорит по-французски, достаточно было бы одну первую его фразу написать по-французски, а остальные по-русски, исключая каких-либо двух-трех, особенно характеристических оборотов, и мы без труда догадались бы, что вся тирада произнесена на французском языке [2. Р. 208].

[We would remark to the author that what appears strange in his novel is not this use of French phrases together with Russian ones, but rather the inordinate filling of dozens of pages with French dialogue. In order to show that Napoleon or some other character speaks French, it would have been enough to give his first words in French and the rest in Russian, with the exception of two or three especially characteristic turns of phrase, and we would have had no trouble guessing that the entire tirade was pronounced in French (Unless otherwise indicated, all translations are my own).]

Tolstoy himself went back and forth over what to do textologically with the French passages. In Russkii vestnik and the first two book editions (both from 1868), the French was glossed in footnotes with Tolstoy's own translations into Russian. In the third edition (1873), the French passages were eliminated and replaced by Russian in the main text, and then reinstated in the 1886 edition [3. Pp. 1, 2]. Even Tolstoy's translation of the French passages, as Morson observes, "borders on the macaronic, a mixture of two languages. Tolstoy's footnotes are not just an aid, but an intrinsic part of his work because he creates a curious dialogue between them and the text" [1. P. 48]. Translators of War and Peace have rendered the French passages in various ways; the English translation by Anthony Briggs (2005) does not use French at all, while that by Richard Pevear and Larissa Volokhonsky (2007), as well as Amy Mandelker's 2010 revised version of the Maude translation, retain the original French passages in their entirety. The challenge of translating the translingual elements in War and Peace is particularly apparent when French is the target language, because the code-switching between French and Russian in the original becomes by default less marked. The 1963 French translation by Elisabeth Guertik compensates for this by italicizing the passages that appear in French in the original [5]. 
Several literary scholars have analyzed the functions of French in the Russian text. V.V. Vinogradov [6. P. 146]. and Viktor Shklovsky both characterized War and Peace as a bilingual novel [4. P. 158]. R.F. Christian argued against this view, estimating that only around 2 percent of the novel's text is in French [9]. Yet as Morson points out, two percent of the text corresponds to about 40 pages, which "could itself be a short novel" [1. P. 48]. Furthermore, the proportion of French to Russian in the novel is much higher if we include dialogues conveyed to the reader in Russian, but which, as we are told by the narrator, take place in another language. For example, when Nikolai Rostov confides to his sister Natasha that he has decided to marry Sonya, their dialogue is conveyed entirely in Russian, yet the narrator specifies that Nikolai speaks French in a whisper:

- Наташа, - сказал он ей шепотом по-французски, - знаешь, я решился насчет Сони [7. Vol. 1. Р. 844].

Issues of language and translation "sit at the heart of contemporary literary inquiry", as Mary Louise Pratt argues [8]. Recent research on literary translingualism has the potential to shed new light on canonical works such as War and Peace, illuminating facets of this novel, as well as the workings of multilingual literature in general. This article examines how information about who speaks what language to whom, how, and why is conveyed in the narrative of War and Peace, with the aim of making the translingual dimension of Tolstoy's masterpiece more visible. First, I will briefly survey the conclusions of previous scholarship on the role of different languages in War and Peace. Then I will analyze selected passages containing more than one language. I will focus especially on meta-linguistic commentary in the novel, showing how it serves to draw attention to language as a medium.

\section{Previous scholarship}

One explanation for the presence of French in War and Peace is realism, i.e. the naturalistic effect of French spoken by the characters - major and minor, historical and fictional alike. The editors of Russkii vestnik offtered this explanation to the journal's readers in a footnote prefacing Tolstoy's own footnotes with translations of the French passages: "To maintain the atmosphere of the conversation of the characters, the author very often uses French expressions" [7. P. 1-2].

Indeed, French held a special status among the Russian nobility throughout the eighteenth- and nineteenth-century, ever since Peter the Great's reforms opened Russia to cultural influences from Western Europe. As Derek Offord, Gesine Argent, Vladislav Rjéoutski and Lara Ryazanova-Clarke point out:

Multilingualism in late eighteenth- and early nineteenth-century Russia was also due to the spread of French across Europe as a language of diplomacy, the lingua franca of the polite society frequented by aristocracies, the vehicle for a refined secular literature and, crucially, the principal means of communication in the so-called Republic of Letters [9. P. 2].

Despite the threat to the nobility represented by the French Revolution in 1789 and Napoleon's invasion of Russia in 1812, the use of French among the Russian nobility did not begin to decline until the mid-nineteenth century [9. P. 3]. Multilingualism was 
thus a reality of life for the Russian nobility of the early nineteenth century, the elite depicted in War and Peace. The French language also played a significant role for the creation of a national Russian literature. It would not be an exaggeration to say that French helped bring Russian literature to the world, in that French served as "a medium of literary activity and a language of sociability among Russian writers of the first half of the nineteenth century" [9. P. 6]. As Brian Baer points out, "A relatively small, highly homogenous polyglot elite, the Russian educated classes of the two capitals, relied to a great extent on translations of Western literature to lay the foundations of modern Russian literature" [10. P. 17]. Yet there is a gap of six decades between the world depicted in the novel (1805-1820) and the context of its creation (the 1860s), at which point the use of French among the Russian nobility had begun to decline. The novel Anna Karenina, which also contains passages in French, comprises a contrasting case, written (18731877 ) as it was very close in time to the period it depicts [11]. The question of the role of French in War and Peace is further complicated by the fact that Russia's war with Napoleon is at the center of the plot. As Shklovsky observes, "The language of the novel's characters is not the language spoken by people in 1812, but rather the language of people remembering the year 1812" [2. P. 205]. R.F. Christian views gallicisms in the Russian text as a "period detail" intended to enhance the novel's realism:

It can be argued that Tolstoy was deliberately using an archaic, Gallicized syntax as a period detail in order to recapture the flavor of the languages spoken in the days of his characters. [...] Secondly, one can say that Tolstoy's Gallicized syntax is not atypical of the Russian language as spoken in his own day, when the influence of French constructions was still strong and when the French language was known at least as well as Russian by most educated men. This fact undoubtedly explains some 'mistakes' in War and Peace, but does not explain their absence in other contemporary novels. Thirdly, one can give credence to Tolstoy's own statement on the subject of language: 'I like what is called incorrectness, that is to say what is characteristic.' His words could be taken to strengthen the suggestion that he deliberately tried to capture the inaccuracies of the living spoken word, the looseness of syntax, the unfinished sentences of the average speaker [4. P. 155].

Tolstoy himself, in his essay "A Few Words Apropos of the Book War and Peace", names the nobility's use of French as one of the aspects of the Napoleonic era he sought to capture, and he justifies his inconsistent use of French in the novel with a striving not for a documentary effect, but an artistic one:

Упрек в том, что лица говорят и пишут по-французски в русской книге, подобен тому упреку, который бы сделал человек, глядя на картину и заметив в ней черные пятна (тени), которых нет в действительности. Живописец неповинен в том, что некоторым - тень, сделанная им на лице картины, представляется черным пятном, которого не бывает в действительности; но живописец повинен только в том, ежели тени эти положены неверно и грубо. Занимаясь эпохой начала нынешнего века изображая лица русские известного общества, и Наполеона, и французов, имевших такое прямое участие в жизни того времени, я невольно увлекся формой выражения того французского склада мысли больше, чем это было нужно. И потому, не отрицая того, что положенные мною тени вероятно, неверны и грубы, я желал бы только, чтобы те, которым покажется очень смешно, как Наполеон говорит то по-русски, то по-французски, знали бы, что это им кажется только оттого, что они, как человек, смотрящий на портрет, видят не лицо с светом и тенями, а черное пятно под носом [13. Рp. 357-358]. 
The reproach that people speak and write in French in a Russian book is similar to the reproach made by a man who, looking at a painting, notices black spots in it (shadows) that are not found in reality. The painter is not to blame if the shadow he has made on the face in the painting looks to some like a black spot that does not exist in reality, but is to blame only if those shadows are laid on incorrectly and crudely. Studying the period of the beginning of the present century, portraying Russian figures of a certain society, and Napoleon, and the French, who took such a direct part in the life of that time, I was involuntarily carried away more than necessary by the form of expression of that French way of thinking. And therefore, without denying that the shadows I laid on are probably incorrect and crude, I wish only that those to whom it seems very funny that Napoleon speaks now in Russian, now in French, should know that it seems so to them because, like the man looking at the portrait, they see not a face with light and shadow, but only a black spot under its nose [13. P. 1218].

The functions of French in War and Peace are not limited to realism, however. While the presence of French arguably enhances the realistic style of the novel, it does much more than that.

R. F. Christian draws a distinction between gallicisms in Tolstoy's Russian, on the one hand, and the direct use of French, on the other. He considers the former "rather an unconscious reflection of the language of educated Russian society in [Tolstoy's] day than a conscious linguistic device", while the latter is, in his view, "equally contrived and equally important in an examination of the style of War and Peace". Christian sees the French passages as a device of characterization, revealing something about the speaker's background, attitudes, and morals. Karin Beck has examined how the "complex and competitive play of linguistic systems - French and Russian" [3. P. 1] in Tolstoy's depiction of Napoleon serves to make fun of him and also further the thesis of the novel's historical essays, namely that history is not made by great men. Shklovsky speculates that the irony in Tolstoy's depiction of Napoleon was lost on contemporary French readers precisely because it was conveyed partly through the interplay of French and Russian, which was lost in French translation [2. P. 219]. The characters' language preferences signal changing attitudes toward Napoleon. Especially later in the novel, after Napoleon's invasion of Russia, the use of French stands in contrast to what is portrayed as authentic Russian.

The French language in War and Peace further serves as a vehicle for social criticism, directed primarily at the Russian nobility. Pratt argues that in literature, "heterolingualism appears not when realism calls for it, but when writers undertake to explore linguistic difference as a social force, a site of power, and a source of knowledge" [2. P. 289]. There are several terms for the use of multiple languages in a literary text. I have chose to use Kellman's term "literary translingualism" here. Other terms include: heterolingualism, polylingualism, and exophone literature. The narrative of War and Peace reveals how the characters' choice of language, like other aspects of their behavior, is always contextual, influenced by setting and social situations. Christian notes that "irony and ridicule of the theatrical and the self-important underly most of the French phrases used in War and Peace" [2. P. 161]. Christian goes on to make the curious argument that as such they serve a legitimate purpose as long as French is readily understood by the reader. But when that 
language ceases to be understood and there is a need for footnotes to explain the meaning, their purpose is no longer useful. This is not say that they ought to be deleted. It is only to emphasize that a knowledge of both French and Russian is essential for a full appreciation of the language of Tolstoy's novel [4. P. 161]. While I do not agree with Christian's statement that knowledge of both languages is requisite to a full appreciation of the work, I think it raises a relevant question concerning readers' proficiency and how meanings are created through the reading process Offord, Rjéoutski and Argent argue that "French is inextricably associated in Tolstoy's eyes with the hypocrisies, ambitions, and stratagems of the social milieu in which it is spoken. It is a language in which speakers dissemble, play roles, and behave histrionically" [14. P. 544]. As these authors point out, French signals sensuality - Anatole Kuragin speaks French when trying to seduce Natasha, as does his sister Hélène with Pierre - and superficiality, on full display at Anna Pavlovna Scherer's soirées, «на которых [...] собиралась la crême de la véritable bonne société, la fine fleur de l'essence intellectuelle de la société de Pétersbourg, как говорила сама Анна Павловна» [7. Vol. 1. P. 577] / "at which [...] there gathered la crème de la veritable bonne société, la fine fleur de l'essence intellectuelle de la société de Pétersbourg, as Anna Pavlovna herself put it [15. P. 364]. Further, as Offord, Rjétoutski and Argent argue:

Tolstoi's treatment of francophonie in the early nineteenth-century Russian world invites reflection on broader questions concerning the nation's integrity and identity that had resonance in the 1860s. The xenophobic flavour of the novel and in particular Tolstoi's treatment of foreign commanders in the Russian army perhaps answered an emotional need following Russia's humiliating defeat at the hands of Britain and France in the recent war in the Crimea" [14. Pp. 545-546].

Yet just as Tolstoy's use of multiple languages in War and Peace "cannot be reduced to the principle of realism", as Pavel Trost argues [16. P. 56], characterization and social criticism cannot fully account for the presence of French in War and Peace. In his monograph Mater'ial i stil'v romane L'va Tolstogo "Voina i mir" (The Material and Style of Lev Tolstoy's Novel War and Peace), Shklovsky suggests a further dimension of language in this novel. He argues that Tolstoy's use of French evolved over the course of writing it, gaining significance in the process. At first, according to Shklovsky, Tolstoy viewed French as part of the material on which the novel was based (similar, perhaps, to the historical and archival sources he drew on in his depiction of the Napoleonic Wars). Shklovsky argues that initially, Tolstoy put French words in the mouths of his characters in order to signal their social background. Subsequently, however, "As a result of the encroachment of a second language on the novel, a bilingual plan for the novel emerged" [2. P. 247]. Shklovsky argues that, in the second half of War and Peace, Tolstoy begins to use French in another way, "to note the incompatibility of ways of thinking in two different languages" [2. P. 216]. Thus, the French language evolves from source material for the novel into an intrinsic part of its style [2. P. 217]. Shklovsky even suggests that language took on a life of its own in the process of writing War and Peace, and that Tolstoy became increasingly interested in aspects of language itself: "Marked language in general interested Tolstoy", who "forces the reader, as well, to listen to it" [2. P. 213]. Further, Shklovsky holds that, later in the novel, Tolstoy increasingly mixes French and Russian, "making this mixture apparent to the reader" [2. P. 217]. Another way to describe this is "laying bare the device", 
to use a concept coined by Shklovsky in his 1921 study of Lawrence Sterne's Tristam Shandy.

One effect of this code-mixing for the reader is ostranenie ("estrangement" or "defamiliarization"), which Shklovsky had first argued to be essential to art a decade earlier, in his essay "Iskusstvo kak priem" [17]:

И вот для того, чтобы вернуть ощущение жизни, почувствовать вещи, для того, чтобы делать камень каменным, существует то, что называется искусством. Целью искусства является дать ощущение вещи, как видение, а не как узнавание; приемом искусства является прием „остранения“ вещей и прием затрудненной формы, увеличивающий трудность и долготу восприятия, так как воспринимательный процесс в искусстве самоцелен и должен быть продлен [24].

[what we call art exists in order to give back the sensation of life, in order to make us feel things, in order to make the stone stony. The goal of art is to create the sensation of seeing, and not merely recognizing, things; the device of art is the "ostranenie" of things and the complication of the form, which increases the duration and complexity of perception, as the process of perception is its own end in art and must be prolonged] [18. P. 80].

To illustrate his point, Shklovsky cites a number of passages by Tolstoy - from his diary, the story "Kholstomer", and War and Peace. Although the argument here concerns literary language in general and not multilingual literature per se, it is interesting to note that he refers repeatedly to foreign language. For example, he describes automatization as inevitable, observing: «если кто вспомнит ощущение, которое он имел, держа в первый раз перо в руках или говоря в первый раз на чужом языке, [...] то согласится с нами.» / "you will agree with this if you remember the feeling you had when holding a quill in your hand for the first time or speaking a foreign language for the first time" [17. P. 79]. Shklovsky also notes that poetic language «практически он и является часто чужим: сумерийский у ассирийцев, латынь у средневековой Европы, арабизмы у персов, древне-болгарский, как основа русского литературного» / "often is quite literally a foreign language-Sumerian for Assyrians, Old Bulgarian as the basis of literary Russian” [17. P. 93].

In the monograph Bilingual Aesthetics: A New Sentimental Education (2004), Doris Sommer includes foreign language in her enumeration of defamiliarizing devices according to the Formalists: "Wordplay, distractions, detours, foreign words are among the devices of deliberate roughness that make up literary technique" [19. P. 30]. Sommer draws an explicit connection between the transgressive qualities of code-switching, which "plays naughty games between languages, poaching and borrowing, and crossing lines [19. P. 34], and ostranenie as "a surprise effect accomplished by roughening conventional material in unconventional ways" [19. P. 29]. Russian Formalist aesthetic theory in general, along with Shklovsky's analysis of the functions of French in War and Peace, offers a promising line of inquiry into literary translingualism.

\section{Analysis}

The translingualism of War and Peace extends beyond realism, characterization, and social criticism into a metalinguistic dimension that draws the reader's attention to the workings of language itself in ways that potentially break the illusion of the fictional world. This is especially the case when dialogue is conveyed to the reader in Russian with narrative 
comments explaining that other languages were spoken (as when Nikolai confides in Natasha in the passage quoted above). As Boris Uspensky observes, "the reporting of a character's speech in either French or Russian is not always dependent upon what language that particular character, at that moment, is assumed actually to have spoken (in the imagination of the author)" [20. P. 46]. The multlingual dimension of the novel becomes more apparent when we consider the numerous instances of metalinguistic commentary. Often the text states explicitly not only which language is being spoken, but also how, and sometimes even why. We also learn how certain characters perceive the language use of others.

To better understand the function of such passages, it is useful to apply the concept of transmesis, coined by Thomas $\mathrm{O}$. Beebee, as "a metaphorical conjunction of translation and mimesis" to analyze how "multilingual realities" are depicted in literary texts [21. P. 3] and "what happens when one language is used as the sign of another" [21. P. 16].

Beebee uses the image of a "black box" to symbolize the difficulty of pinpointing how such depictions work:

Like mind, language resists representation, though for a different reason: mind is nowhere, while language is everywhere. Grammars and dictionaries generally analyze their respective languages rather than miming them. The problem of language mimesis thus resembles that of representing the infinitely large, while mind leads us to the problem of the black box. The black box contains an algorithm that is hidden and unknown; language, on the other hand, is too open, too all encompassing, to be surveyed. One way of miming language, it turns out, involves translating it [21. P. 5].

Beebee identifies four different categories of literary texts that constitute transmesis:

[1] Texts whose mimetic object is the act of translation, the translator, and his or her social and historical contexts.

[2] Texts that overtly claim to be translations, though no 'original' exists. [i.e. pseudotranslation]

[3] Texts that mime a language reality such that the medium does not match the object depicted (e.g., when conversations taking place in Cuba between Cubans are given in English).

[4] Texts that make standard language strange to itself [...], inasmuch as such departures are seen as the result of transcoding from another, more 'original' language; code-switching; interference from another language; and so forth [21. P. 6].

While category [2] is not relevant in the case of War and Peace, the other three categories are all present within it, as I will show below in some examples of translingual passages that serve to draw the reader's attention to language itself. Since there is not scope here for a comprehensive analysis of translingual elements in the novel, the discussion will merely trace the contours of what a fuller translingual reading of Tolstoy's novel might reveal.

\section{Who speaks what language(s) to whom, how and why in War and Peace?}

The distribution of languages in the novel is inconsistent and unsystematic, defying in most cases any direct correlation between a character and a particular language. As Uspensky points out, "both the French characters and the Russian aristocracy use both languages in the novel, expressing themselves in Russian, or in a mixture of French and 
Russian" [20. P. 46]. Shklovsky argues that the main characters of War and Peace can be divided into two groups based on language compentency: "those who speak French well and those who speak French poorly" [2. P. 211]. Further, Shklovsky makes the observation that native speakers do not serve as role models in this respect: "French characters who speak French in the novel are not represented by Tolstoy as the ideal of the French language; in particular, he faults Mademoiselle Burienne for mispronouncing $r$ and $l$, and Napoleon for over-articulating" [2. P. 211].

We might then ask which characters in War and Peace display the highest proficiency in French. I would argue that Pierre Bezukhov and Andrei Bolkonsky are portrayed as the most competent code-switchers in the novel, and multiple passages show them making use of different languages and even accents. Their linguistic dexterity is in line with other qualities attributed to them, such as "the ability to respond to change, the qualities of restlessness, curiosity, flexibility and dynamism", which Christian sees as "perquisites of the main heroes of the novel, and in particular Pierre, Prince Andrei and Natasha" [4. P. 176]. Early on, the narrative repeatedly shows Andrei making conscious choices about language, some of which may surprise twenty-first century readers. For example, he speaks not Russian but French to Kutuzov; although the entire passage is in Russian, the narrator specifies that Andrei addressed him "quietly in French" [15. P. 118]. When Andrei's attention is required by an old Russian general toward whom he feels contempt, he chooses to speak to him in Russian overlaid with "that French pronunciation which he used when he wanted to speak disdainfully" [15. Р. 249] / «тем французским выговором, которым он говорил, когда хотел говорить презрительно» [7. Vol. 1. P. 394].

Andrei's multilingual proficiency is further evidenced by mention in the narrative that he "had translated the articles of the Roman and French [legal] codes into Russian" [15. P. 466]. Pierre, as well, is depicted translating, when he interprets between French and German for members of Napoleon's army occupying Moscow. As Offord, Rjéoutski and Argent note, "Pierre has the ability to assimilate foreign languages and cultures" [14. P. 549]. The passages depicting Andrei translating texts and Pierre interpreting speech both fall into Beebee's first category of "Texts whose mimetic object is the act of translation, the translator, and his or her social and historical contexts".

\section{Metalinguistic commentary}

Many passages in War and Peace in which more than one language come into play serve to highlight not the characters' language proficiency or bilingualism, but rather moments of failed communication, incomprehensibility, and the gaps between languages. One such example is the scene in which the character Dolokhlov is introduced to the reader, at the same time that Pierre encounters him for the first time. Dolokhov is portrayed involved in a bet during a night of carousing. One of participants is the Englishman Stevens, and although the dialogue in this passage is conveyed in Russian, a parenthetical comment informs the reader that Dolokhov "spoke in French so that the Englishman would understand him, and he did not speak the language all that well" [15. P. 33]. This passage thus exemplifies Beebee's third category, in that it depicts "a language reality such that the medium does not match the object depicted". Stevens' reply to Dolohhov is given in Russian, thus calling on the reader to suspend disbelief and imagine that he is actually speaking English. Anatole Kuragin then "began repeating the conditions of the 
bet to him in English" [15. P. 33], thus confirming the limited comprehensibility of Dolokhov's French indicated by in the above-mentioned parenthetical comment. His speech is not conveyed directly, but merely paraphrased in this way, yet the narrator makes note of his choice of language. What follows is a moment of incomprehension - or perhaps merely the denial of comprehension: "The Englishman nodded his head, in no way making clear whether he did or did not accept this new bet" [15. P. 33].

Another example of Beebee's third category, in which the language used in the narrative does not correspond to the language of the depicted dialogue, occurs when Kutuzov speaks with an Austrian general and Prince Andrei, who is serving as Kutuzov's adjutant, enters the room. Here, too, we are told not only which language is spoken, but how:

- А... сказал Кутузов, оглядываясь на Болконского, как будто этим словом приглашая адъютанта подождать, и продолжал по-французски начатый разговор.

- Я только говорю одно, генерал, - говорил Кутузов с приятным изяществом выражений и интонации, заставлявшим вслушиваться в каждое неторопливо сказанное слово. Видно было, что Кутузов и сам с удовольствием слушал себя [7. Vol. 1. Рp. 192_ 193].

"Ah..." said Kutuzov, glancing at Bolkonsky, as if with this word he was inviting the adjutant to wait, and went on with the conversation begun in French.

"I'm saying only one thing, General", Kutuzov said with a pleasant graciousness of expression and intonation, which made one listen well to every unhurriedly uttered word. It could be seen that Kutuzov, too, listened to himself with pleasure [15. P. 122].

This brief passage, which contains the words word (twice), saying, and uttered, emphasizes language in several ways: the omniscient third-person narrator interprets for the reader the monosyllabic interjection "Ah..." as an invitation to wait; Kutuzov comments on his own speech ("I'm saying only one thing"); and his manner of speaking is commented on by the narrator ("with a pleasant graciousness of expression and intonation, which made one listen well to every unhurriedly uttered word"); in response to Kutuzov's manner of speaking, the addressees "listen well", and even Kutuzov "listened to himself with pleasure". By constantly drawing attention to the medium in this passage, the reader, too, is made to "listen well" to language while reading this passage, not only taking in, cognitively, its content (the "one thing" Kutuzov is saying to the Austrian general), but experiencing the sensory effects of what is said within it. This passage also prepares the reader for the code-switching that occurs throughout this chapter, which quotes directly in German from a letter from Archduke Ferdinand and contains phrases of dialogue in German and French.

The above examples show the degree of detail in Tolstoi's depiction of the characters's speech in War and Peace. Uspensky notes “Tolstoy's scrupulousness and almost pedantic attention to the transmission of the phonetic peculiarities of the characters" [20. P. 46]. Such comments on language - what language is spoken, how and why - often appear in parentheses, which interrupt the narrative flow to give information about the means of communication, momentarily drawing the reader's attention from a focus on what to how, away from the content of the text toward its linguistic form.

In addition to code-switching, numerous passages in War and Peace exhibit codemixing, with a higher degree of permeation of languages and their sphere of references. As Gary Saul Morson observes, "the French language is so woven into this text that it cannot be removed mechanically" [1. P. 49]. 
A good example of code-mixing, noted by Uspensky, is the passage depicting how Napoleon glimpses Moscow for the first time:

Cette ville asiatique aux innombrables églises, Moscou la sainte. La voilà donc enfin, cette fameuse ville! Il était temps, - сказал Наполеон и, слезши с лошади, велел разложить перед собою план этой Moscou и подовзал переводчика Lelorgne d'Ideville [7. Vol. 2. P. 433].

"Cette ville asiatique aux innombrables églises, Moscou la sainte, La voilà donc enfin, cette fameuse ville! Il était temps", said Napoleon and, getting off his horse, he ordered a map of this Moscou spread out before him and summoned the interpreter Lelorgne d'Ideville [15. P. 871].

Here, the French word for Moscow indicates that Napoleon is the focalizer: the Russian city Moskva is seen from the specific perspective of the French Emperor, as Moscou. Uspensky explains, Tolstoy feels it necessary to show the actual pronunciation of this particular word from Napoleon's position, while all the other words of the same sentence are given in Russian from a different position. Sentences of this kind may be viewed as the result of the synthesis (an indivisible combination) of the French phrase as it was supposed to have been pronounced and the Russian translation of it [20. P. 53].

Furthermore, the two different scripts - Cyrillic and Latin - used in the passage serve to draw the reader's attention to the language and its materiality. In the phrase этой Moscou, a French word is given a Russian modifier, which is declined as if it were modifying the Russian noun Москва. Shklovsky mentions, albeit only very briefly, that Tolstoy uses transcription as a means of ostranenie [2. P. 216; 29].

As with other translingual elements in War and Peace, transcription is not employed systematically; at one point in Nikolai Rostov's speech, French is transliterated into Russian, set off only by italics: «И Берг тут! Ах ты, петизанфан, але куше дормир!», as if his to remind the reader that language can look different than we expect, fulfilling Beebee's fourth category, of "texts that "make standard language strange to itself".

\section{Conclusion}

"Transmeses", holds Beebee, "remind their readers that the universe is multilingual".

By frequently drawing the reader's attention to language itself, War and Peace reminds us that the fictional world of Pierre, Andrei, Natasha is multilingual, as is our own. There is no one simple explanation for the complex interplay of different languages in War and Peace. Translingual elements appear in various forms within the fictional world it depicts, as well as on the level of the text. The inconsistencies in the way language use is attributed to characters, as well as variations in how it is depicted and conveyed in the novel, create a deautomatizing effect for readers, forcing them, as Shklovsky observes in a passage quoted above, to listen to language [2. P. 213].

As the brief survey of previous studies shows, the translingual elements in War and Peace can be seen to have a variety of functions and effects, contributing to the novel's realism, characterization, and social criticism. Drawing on Shklovsky's work, I have focused in my analysis of selected passages on the metalinguistic dimension opened up by translingualism in the text. The many instances of metalinguistic commentary highlight, in the words of Shklovsky, "the incompatibility of ways of thinking in two different 
languages" [4. P. 216]. Many earlier translations of Tolstoy's novel into other languages attempt to bridge this incompatibility, rendering the rich interplay of languages in Tolstoy's novel less visible than in the original. This situation is changing, however, thanks to several recent translations that preserve the French passages. The time is now ripe for critical re-readings of this canonical novel through the new lenses offered by recent scholarship in the burgeoning field of translingual literary studies.

\section{References}

1. Morson, Gary Saul. 1987. Hidden in Plain View: Narrative and Creative Potentials in 'War and Peace'. Stanford: Stanford University Press. Print.

2. Shklovsky, Viktor. 1928. Mater'ial i stil'v romane L'va Tolstogo “Voina i mir”. Moskva: Federatsiia. Print.

3. Beck, Karin. 2009. "The Emperor Has No Voice! How Not to Do Things with Words in War and Peace". Tolstoy Studies Journal XXI: 1-14. http://ezproxy.its.uu.se/login?url=https://searchproquest-com.ezproxy.its.uu.se/docview/822741849?accountid=14715 P. 1-2.

4. Christian, R.F. 1962. Tolstoy's 'War and Peace': A Study. Oxford: Clarendon. 1962. Print

5. Tolstoï, Léon. 1963. Le Guerre et la Paix. Trans. by Elisabeth Guertik. Vol. 1. Paris: Le Livre de Poche. Print.

6. Vinogradov, V. 1939. O iazyke Tolstogo: 50-60-e gody. Moskva: Izdatel'stvo AN SSSR. http:// feb-web.ru/feb/litnas/texts/135/t35-117-.htm?cmd=p

7. Tolstoi, Lev. 2018. Voina i mir. Vol. 1-2. Moskva: Izdatel'stvo AST. Print

8. Pratt, Marie Louise. 2011. "Comparative Literature and the Global Languagescape". A Companion to Comparative Literature. Ali Behdad and Dominic Thomas, eds. Hoboken: Blackwell, 2011. 273-295. Print. 274.

9. Offord, Derek, Gesine Argent, Vladislav Rjéoutski, and Lara Ryazanova-Clarke. 2015. "Introduction." In French and Russian in Imperial Russia: Language Use among the Russian Elite. Derek Offord, Lara Ryazanova-Clarke, Vladislav Rjéoutski, and Gesine Argent, eds. Edinburgh: Edinburgh University Press. 1-24. Print.

10. Brian James Baer. 2016. Translation and the Making of Russian Literature. London: Bloomsbury. Print. P. 17.

11. Christian, R.F. 1967. "The Passage of Time in Anna Karenina". The Slavonic and East European Review 45.104: 207-210. Print.

12. Tolstoi, L.N. 1981. "Neskol'ko slov po povodu knigi 'Voina i mir'”. Sobranie sochinenii. Vol. 7. Moskva: Khudozhestvennaia literature. P. 356-365. https://rvb.ru/tolstoy/01text/vol_7/0030_6. htm

13. Tolstoy, Leo. 2007. "A Few Words Apropos of the Book War and Peace”. In War and Peace. Trans. by Richard Pevear and Larissa Volokhonsky. New York: Knopf. 1217-1224. Print.

14. Offord, Derek, Vladislav Rjéoutski, and Gesine Argent. 2018. The French Language in Russia: A Social, Political, Cultural, and Literary History. Amsterdam: Amsterdam University Press. Print.

15. Tolstoy, Leo. 2007 War and Peace. Trans. by Richard Pevear and Larissa Volokhonsky. New York: Knopf. Print.

16. Trost, Pavel. 1995. “K dvojjazyčnosti Vojny a míru”. In Studie a jazycích a literatuře. Praha: Torst. 52-57. Print.

17. Shklovsky, Viktor. "Iskusstvo kak priem”. http://www.opojaz.ru/manifests/kakpriem.html

18. Shklovsky, Viktor. 2017. "Art as Device". In Viktor Shklovsky: A Reader. Trans. by Alexandra Berlina. London: Bloomsbury. P. 73-96. Print.

19. Sommer, Doris. 2004. Bilingual Astethetics: A New Sentimental Education. Durham: Duke University Press. Print.

20. Uspensky, Boris. 1973. A Poetics of Composition: The Structure of the Artistic Text and Typology of a Compositional Form. Trans. by Valentina Zavarin and Susan Wittig. Berkeley: University of California Press. Print. 
21. Thomas O. 2012. Transmesis: Inside Translation's Black Box. New York: Palgrave Macmillan. Print.

\title{
Article history:
}

Received: 10.09.2019

Accepted: 10.10.2019

Moderator: S.G. Kellman

Conflict of interests: none

For citation:

Hansen, J. 2019. "Reading War and Peace as a Translingual Novel". Polylinguality and Transcultural Practices, 16 (4), 608-621. DOI 10.22363/2618-897X-2019-16-4-608-621

\section{Bio Note:}

Julie Hansen is Associate Professor of Slavic Languages at Uppsala University in Sweden. In addition to numerous articles on literary multilingualism and translation, she is co-editor of the volume Transcultural Identities in Contemporary Literature (Rodopi 2013) and the special issues "Contexts of Russian Literary Translation" of (Translation and Interpreting Studies, 2016) and "Translingualism and Transculturality in Russian Contexts of Translation" (Translation Studies 2018).

\section{Читая «Войну и мир» как транслингвальный роман}

\author{
Дж. Хансен \\ Университет Упсалы \\ 75236 Uppsala, Швеция
}

\begin{abstract}
В этой статье роман Льва Толстого «Война и мир» пересматривается в свете недавних исследований в области межъязыкового литературоведения. Этот русский роман содержит многочисленные отрывки, фразы и слова на французском языке. Использование Толстым французского языка в русском романе озадачило многих современных ему критиков; этот факт менее заметен при переводе на другие языки. В статье рассматриваются предыдущие исследования многоязычного измерения войны и мира, проведенные такими известными учеными, как В. Виноградов, В. Шкловский, Б. Успенский, Р.Ф. Кристиан и Гари Саул Морсон. Среди объяснений присутствия французского языка в тексте - реализм, характеристика и остранение (дезамиграция). Применяя принципы формализма и концепцию трансмезиса Томаса О. Биби, автор предлагает прочтение этого канонического романа на разных языках. Анализ сфокусирован на отдельных отрывках, в которых задействованы несколько языков, и показывает, как они привлекают внимание читателя к языку как к средству изображения через переключение кода и многоязычных ситуаций; металингвистический комментарий; бискриптивизм; и микширование кода на уровне текста.
\end{abstract}

Ключевые слова: Толстой, «Война и мир», многоязычный, двуязычный, французский, трансмезис 


\section{История статьи:}

Дата поступления в редакцию: 10.09.2019

Дата принятия к печати: 10.10.2019

Модератор: С. Келлман

Конфликт интересов: отсутствует

\section{Для цитирования:}

Хансен Дж. Читая «Войну и мир» как транслингвальный роман // Полилингвиальность и транскультурные практики. 2019. Т. 16. № 4. C. 608-621. DOI 10.22363/2618-897X-2019$16-4-608-621$

\section{Сведения об авторе:}

Джулия Хансен - доцент кафедры славянских языков в Упсальском университете в Швеции. В дополнение к многочисленным статьям о литературном многоязычии и переводе она является соредактором тома «Транскультурные идентичности в современной литературе» (Rodopi 2013) и специальных выпусков «Контексты русского литературного перевода» («Переводы и устные переводы, 2016») и « Транслингвизм и транскультурность в российских контекстах перевода» (Переводоведение 2018). 